\title{
EFEK PENGURANGAN DAN PEMENUHAN KEMBALI JUMLAH PAKAN TERHADAP KONSUMSI DAN KECERNAAN BAHAN PAKAN PADA KAMBING KACANG DAN PERANAKAN ETAWAH
}

\section{EFFECT OF REDUCTION AND REFULFILLMENT OF FEED QUANTITY ON FEED INTAKE AND NUTRIENT DIGESTIBILITY OF KACANG AND ETAWAH CROSSBRED GOAT}

\author{
Aryanto $^{1 *}$, Bambang Suwignyo ${ }^{2}$, dan Panjono ${ }^{2}$ \\ ${ }^{1}$ Balai Pengkajian Teknologi Pertanian (BPTP) Sulawesi Utara, Jl. Kampus Pertanian, Desa Kalasey I Dusun IV, \\ Kecamatan Mandolang, Kabupaten Minahasa, 95013 \\ ${ }^{2}$ Fakultas Peternakan, Universitas Gadjah Mada, Jl. Fauna No. 3, Bulaksumur, Yogyakarta, 55281
}

\section{INTISARI}

Penelitian bertujuan untuk mengetahui efek pengurangan dan pemenuhan kembali jumlah pakan terhadap konsumsi dan kecernaan bahan pakan pada kambing Kacang dan Peranakan Etawah. Delapan ekor kambing jantan yang terdiri atas 4 ekor kambing Kacang dan 4 ekor kambing Peranakan Etawah digunakan dalam penelitian ini. Kedua jenis kambing tersebut diberikan perlakuan yang sama. Pertama, pakan dikurangi dengan pemberian bahan kering 1,7\% berat badan untuk masing-masing ternak, kedua, ternak diberi pakan secara ad libitum. Variabel yang diamati adalah konsumsi dan kecernaan pakan. Data yang diperoleh dianalisis dengan uji Sidik Ragam menggunakan Rancangan Acak Lengkap (RAL) pola faktorial 2x2. Uji Jarak Berganda Duncan digunakan untuk menguji perlakuan yang berbeda nyata. Hasil penelitian menunjukkan bahwa bangsa kambing dan volume pakan tidak saling berinteraksi untuk mempengaruhi kemampuan konsumsi dan kecernaan pakan. Perbedaan bangsa kambing tidak berpengaruh terhadap konsumsi bahan kering dan bahan organik, akan tetapi kambing Peranakan Etawah mampu mencerna bahan kering dan bahan organik secara lebih baik $(\mathrm{P}<0,05)$ daripada kambing Kacang. Perbedaan volume pakan mempengaruhi $(\mathrm{P}<0,01)$ konsumsi bahan kering, konsumsi bahan organik, kecernaan bahan kering, dan kecernaan bahan organik. Disimpulkan bahwa konsumsi dan kecernaan pada kedua bangsa kambing mempunyai pola yang sama, yang akan menurun saat pakan dikurangi dan meningkat secara signifikan ketika pakan diberikan ad libitum.

(Kata kunci: Kambing, Pengurangan pakan, Konsumsi dan kecernaan)

\section{ABSTRACT}

The aim of this study was to observe the effect of reduction and refulfillment of feed quantity on feed intake and nutrient digestibility of the Kacang and Etawah crossbred goat. Eight goats consisted of 4 Kacang and 4 Etawah crossbred goats were used in the study. These two types of goats were subjected to the same treatment. The first feeding trial was reduced by the dry matter of $1.7 \%$ of body weight for each goat, the second trial given ad libitum feeding. The observed variables were feed intake and nutrient digestibility. Data were analyzed variance using Completely Randomized Design (CRD) with 2x2 factorial arrangement. Duncan's new Multiple Range Test was used to test the significant difference between the treatments. The results showed that volume of feed and type of goats did not interact each other to affect the consumption and digestibility of feed. Difference of the goat type has no significant effect on the intakes of dry matter and organic matter but Etawah crossbred goats were able to digest dry matter and organic matter greater $(P<0.05)$ than Kacang goats. Different volume of feed affected $(P<0.01)$ dry matter intakes, organic matter intakes, dry matter and organic matter digestibility. It was concluded that feed intakes and digestibility of both types of goats have the same pattern, decreasing when the feed was reduced, and increasing significantly when the feed was given ad libitum.

(Key words: Goat, Feed reduction, Consumption and digestibility)

\footnotetext{
* Korespondensi (corresponding author):

Telp. +6281340075423

E-mail: aaryant6@gmail.com
} 


\section{Pendahuluan}

Kambing Kacang dan kambing Peranakan Etawah (PE) adalah dua di antara keberagaman bangsa kambing yang dikenal saat ini. Kedua bangsa kambing tersebut merupakan jenis kambing yang paling dominan di Indonesia. Menurut Devendra dan Burns (1994), kambing Kacang adalah kambing asli Malaysia dan Indonesia yang merupakan tipe penghasil daging. Kambing PE sebagaimana dinyatakan oleh Wirawan et al. (2008) merupakan persilangan antara kambing Etawah dan kambing Kacang yang bersifat dwiguna yaitu sebagai penghasil daging dan susu. Kedua jenis kambing tersebut tentunya mempunyai karakteristik yang berbeda dalam merespon lingkungannya.

Konsumsi pakan merupakan hal mendasar yang akan menentukan level nutrien, fungsi dan respon ternak serta penggunaan nutrien dalam pakan (Arora, 1995). Ternak ruminansia akan mengkonsumsi pakan dalam jumlah tertentu untuk memenuhi kebutuhan hidup pokoknya, kemudian konsumsi pakan akan meningkat sejalan dengan perkembangan kondisi dan tingkat produksi yang dihasilkannya. Mulyono dan Sarwono (2010) menyatakan bahwa volume pakan yang diperlukan kambing sangat tergantung dari total berat badan dan kemampuan memakan pakan (aseptabilitas). Orskov (1988) menyatakan bahwa kapasitas rumen akan menentukan tingkat konsumsi pakan, karena ternak akan berhenti makan ketika rumennya telah penuh terisi pakan meskipun kebutuhan nutriennya belum terpenuhi.

Kecernaan bahan pakan adalah rangkaian perubahan fisik dan kimia yang dialami bahan pakan dalam saluran pencernaan. Kecernaan dapat dijadikan indikasi awal ketersediaan nutrien yang dikandung bahan pakan sebagaimana dinyatakan oleh Paramita et al. (2008) bahwa besarnya kecernaan akan menentukan banyaknya nutrien yang dapat dimanfaatkan untuk memenuhi kebutuhan hidup pokok dan pertumbuhan. Senada dengan itu, Yusmadi (2008) menyatakan bahwa kecernaan yang tinggi mencerminkan besarnya sumbangan nutrien tertentu pada ternak, sedangkan pakan yang kecernaannya rendah menunjukkan bahwa pakan tersebut kurang mampu menyuplai nutrien untuk hidup pokok dan tujuan produksi ternak.

Kualitas bahan pakan dapat dilihat pada besarnya pengaruh terhadap penampilan ternak melalui konsumsi dan kecernaan bahan pakan tersebut. Paramita et al. (2008) menyatakan bahwa konsumsi pakan berkaitan dengan kecernaan nutrien yang dikandung, sedangkan kecernaan dipengaruhi oleh jumlah serta kandungan nutrien yang dikonsumsi oleh ternak. Namun demikian tidak dapat dipungkiri bahwa penampilan ternak tidak hanya dipengaruhi oleh kualitas bahan pakan akan tetapi jumlah pakan yang tersedia juga menjadi faktor pembatas di waktu tertentu.

Persoalan yang sering dihadapi peternak dalam mengembangkan usahanya adalah ketersediaan hijauan yang sering berfluktuasi sebagaimana dinyatakan Utomo (2003) bahwa pengembangan peternakan mendapatkan kendala pada penyediaan hijauan pakan secara kontinyu sepanjang musim. Pergantian musim tentunya menyebabkan ketersediaan pakan akan berfluktuasi, di saat musim penghujan produksi mencukupi bahkan melimpah sementara musim kemarau produksinya terbatas. Dengan demikian pemberian pakan bagi ternak juga akan mengikuti pola ketersediaan pakan pada pergantian musim tersebut. Pemenuhan pakan ternak seperti tersebut secara langsung akan berpengaruh terhadap performans ternak yang ada.

Sehubungan dengan uraian di atas maka perlu dilakukan penelitian untuk mensimulasikan kondisi pakan terbatas dan pakan melimpah sebagai dampak dari pergantian musim kemarau dan musim penghujan. Tujuan penelitian adalah untuk mengetahui pola konsumsi dan kecernaan bahan pakan pada kambing Kacang dan kambing PE jika pakan dikurangi dan pakan diberikan secara ad libitum.

\section{Materi dan Metode}

\section{Materi}

Ternak percobaan. Ternak yang digunakan adalah 8 ekor kambing jantan berumur rata-rata 1 tahun. Jenis kambing terdiri atas 4 ekor kambing Kacang dengan berat badan awal rata-rata $26,47 \pm 2,54 \mathrm{~kg}$ dan 4 ekor kambing Peranakan Etawah (PE) dengan berat badan awal rata-rata $34,05 \pm 1,46 \mathrm{~kg}$.

Kandang percobaan. Kandang percobaan terdiri atas 1 unit kandang berbentuk panggung dengan petak-petak individu berukuran $1,5 \mathrm{~m} \times 75$ $\mathrm{cm}$ yang dilengkapi dengan tempat pakan dan tempat air minum. Petak-petak individu terbuat dari besi, sedangkan lantai kandang terbuat dari kayu yang dibuat sedemikian rupa sehingga mempermudah proses pembersihan kandang. Tempat pakan menempel di luar bagian depan dari petak individu, sedangkan untuk tempat konsentrat dan air minum digunakan ember yang dimasukkan ke dalam tempat pakan.

Pakan. Pakan yang digunakan terdiri atas hijauan berupa jerami kacang tanah (rendeng) yang dibeli dari petani di wilayah Bantul. Konsentrat yang digunakan adalah konsentrat komersial berbentuk pelet dengan nama Gemuk A produksi PT. Japfa Comfeed Indonesia. Perbandingan 
hijauan dan konsentrat diatur sesuai dengan perlakuan pada setiap periode penelitian.

Alat. Alat yang digunakan adalah timbangan duduk merek five goats kapasitas $10 \mathrm{~kg}$ dengan ketelitian $25 \mathrm{~g}$ untuk menimbang pakan, timbangan analitik merek camry kapasitas $3 \mathrm{~kg}$ dengan ketelitian $1 \mathrm{~g}$ untuk menimbang sampel feses, chopper, parang, ember, rangkaian alat penampung feses, dan alat-alat laboratorium.

\section{Metode}

Penelitian dilaksanakan pada bulan Agustus sampai November 2011, bertempat di kandang percobaan Fakultas Peternakan Universitas Gadjah Mada. Analisis dilakukan di Laboratorium Hijauan Makanan Ternak dan Pastura Fakultas Peternakan Universitas Gadjah Mada.

Pra penelitian. Pra penelitian dilakukan selama satu bulan dimaksudkan untuk membiasakan ternak dengan lingkungan yang baru.

Rancangan percobaan. Penelitian ini menggunakan Rancangan Acak Lengkap pola faktorial (Hanafia, 2010). Perlakuan terdiri dari 2 faktor yakni, bangsa kambing (kambing Kacang (K1) dan kambing PE (K2)) dan jumlah pakan (pengurangan pakan (BK 1,7\% berat badan (R1) dan pakan ad libitum (R2)). Masing-masing perlakuan terdiri atas 4 ulangan.

Tahapan penelitian. Pelaksanaan penelitian dilakukan dalam dua tahap, tahap pertama berlangsung selama 32 hari yaitu tahap pengurangan pakan, jumlah pakan dikurangi dengan pemberian bahan kering $1,7 \%$ berat badan pada masing-masing ternak. Perbandingan pakan hijauan + konsentrat adalah $60 \%+40 \%$. Tahap kedua berlangsung selama 30 hari yaitu tahap pemenuhan pakan, pakan hijauan jerami kacang tanah diberikan secara ad libitum, sedangkan konsentrat diberikan sebanyak $40 \%$ dari kebutuhan bahan kering untuk hidup pokok (setara 1,2\% berat badan).

\section{Pengambilan data}

Data yang diambil dalam penelitian ini meliputi konsumsi bahan kering, konsumsi bahan organik, kecernaan bahan kering dan kecernaan bahan organik.

Konsumsi bahan kering dan bahan organik. Konsumsi pakan dihitung dengan cara mengurangi jumlah pakan yang diberikan dengan sisa pakan yang tidak dimakan oleh ternak. Pakan yang akan diberikan ditimbang terlebih dahulu, sedangkan sisa pakan ditimbang pada pagi hari berikutnya. Perhitungan konsumsi bahan kering (BK) dan bahan organik (BO) adalah mengalikan hasil analisis proksimat bahan kering maupun bahan organik dengan jumlah pemberian pakan kemudian dikurangi dengan sisa pakan yang telah dikalikan dengan hasil analisis proksimat. Perhitungan masing-masing adalah sebagai berikut:

Konsumsi BK (kg/ekor/hari) $=(\%$ BK pemberian $\mathrm{x}$ total pemberian $)$ - (\% BK sisa $\mathrm{x}$ total sisa).

Konsumsi BO (kg/ekor/hari; g/kg berat badan/hari) $=(\% \mathrm{BO} \times \mathrm{BK}$ pemberian $)-(\% \mathrm{BO} \times \mathrm{BK}$ sisa $)$.

Kecernaan bahan kering dan bahan organik. Kecernaan pakan ditentukan dengan metode total koleksi pada tujuh hari terakhir baik pada tahap pengurangan pakan maupun pada tahap pemberian pakan secara ad libitum. Jumlah pakan yang diberikan dan sisanya dicatat setiap hari. Feses yang dikeluarkan selama 1 hari (24 jam) ditampung dan yang tersangkut dalam kandang dikumpulkan lalu ditimbang. Feses yang diperoleh setiap harinya diambil sampel $10 \%$, kemudian dijemur di bawah sinar matahari sampai diperoleh sampel kering matahari (2 hari jemur). Setelah itu, sampel tersebut dioven pada suhu $105^{\circ} \mathrm{C}$ untuk proses analisis selanjutnya. Kecernaan bahan kering pakan (KCBK) dan kecernaan bahan organik (KCBO) masing-masing dapat dihitung dengan rumus:

$$
\begin{aligned}
& \text { KCBK }=\frac{\text { JKBK pakan }- \text { JBK feses }}{\text { JKBK pakan }} \times 100 \% \\
& \text { KCBO }=\frac{\text { JKBO pakan }- \text { JBO feses }}{\text { JKBO pakan }} \times 100 \%
\end{aligned}
$$

Keterangan:

$\mathrm{KCBK}=$ kecernaan bahan kering

$\mathrm{KCBO}=$ kecernaan bahan organik

JKBK = jumlah konsumsi bahan kering

JBK = jumlah bahan kering

$\mathrm{JKBO}=$ jumlah konsumsi bahan organik

$\mathrm{JBO}=$ jumlah bahan organik

$\mathrm{JKBO}=$ jumlah konsumsi bahan organik

\section{Analisis data}

Data yang diperoleh dianalisis dengan sidik ragam sesuai dengan rancangan percobaan yang digunakan. Hasil uji Sidik Ragam yang menunjukkan perbedaan nyata dilanjutkan dengan uji Jarak Berganda Duncan.

\section{Hasil dan Pembahasan}

\section{Konsumsi bahan kering dan bahan organik}

Analisis Sidik Ragam menunjukkan adanya pengaruh yang sangat nyata $(\mathrm{P}<0,01)$ dari perlakuan pakan terhadap konsumsi bahan kering dan konsumsi bahan organik, akan tetapi perbedaan bangsa tidak berpengaruh, dan tidak ada interaksi antara faktor bangsa kambing dan jumlah pakan 
terhadap parameter-parameter tersebut. Konsumsi bahan kering dan bahan organik pakan sebagai akibat dari adanya perlakuan dapat dilihat pada Tabel 1. Tidak adanya interaksi menunjukkan bahwa tidak ada keterkaitan antara bangsa kambing dan jumlah pakan yang mempengaruhi konsumsi bahan kering maupun bahan organik pakan.

\section{Konsumsi bahan kering}

Secara statistik kambing Kacang dan kambing PE mempunyai kemampuan konsumsi bahan kering per kilo gram berat badan relatif sama, namun pada Tabel 1 terlihat bahwa konsumsi bahan kering kambing Kacang cenderung lebih tinggi dari kambing PE. Lebih tingginya konsumsi bahan kering kambing Kacang kemungkinan dipengaruhi oleh faktor kapasitas retikulo-rumen.

Informasi hasil penelitian perbandingan kapasitas saluran pencernaan antara kambing Kacang dan kambing PE saat ini belum ada, namun dengan melihat postur tubuh kambing Kacang yang jauh lebih kecil daripada kambing PE, memunculkan dugaan bahwa kemampuan konsumsi per $\mathrm{kg}$ berat badan yang ditunjukkan kambing Kacang kemungkinan karena persentase volume lambung kambing Kacang terhadap berat badannya lebih tinggi dibandingkan persentase volume lambung kambing PE. Dugaan tersebut tentunya masih perlu pembuktian melalui penelitian lebih mendalam.

Selain kemungkinan perbedaan persentase volume lambung perlu juga membandingkan tingkat konsumsi pakan dengan parameter-parameter lain yang terkait dengan tingkat konsumsi pakan antar lain kecernaan bahan pakan dan pola perubahan berat badan kedua bangsa kambing tersebut. Konsumsi bahan kering pakan meningkat sangat nyata ketika pakan diberikan secara ad libitum. Pemberian pakan sepuasnya memungkinkan aktivitas mikroba rumen dan laju fermentasi menjadi meningkat, kecernaan dan laju partikel makanan dari rumen bertambah sehingga dengan demikian konsumsi juga akan semakin meningkat.

Konsumsi bahan kering per $\mathrm{kg}$ berat badan pada saat pakan dikurangi masing-masing adalah 17,58 g dan ketika pakan diberikan secara ad libitum konsumsi meningkat menjadi $28,78 \mathrm{~g}$. Terjadinya peningkatan konsumsi tersebut merupakan hal yang alami, karena saat pakan dikurangi maka ternak tidak punya kesempatan untuk makan lebih dari yang disediakan sekalipun itu masih di bawah kebutuhan hidup pokoknya. Sebaliknya, ketika diberikan secara ad libitum maka ternak bebas untuk mengkonsumsi pakan yang disediakan sampai sepuasnya, jauh lebih banyak dari yang dikonsumsi saat pakan dikurangi. Selain disebabkan oleh jumlah bahan pakan yang diberikan, tinggi rendahnya konsumsi bahan pakan juga dipengaruhi oleh beberapa faktor. Menurut Tillman et al. (1998), konsumsi bahan pakan pada kambing banyak dipengaruhi oleh laju pencernaan bahan pakan dalam saluran pencernaan, laju pengeluaran sisa pakan yang dikonsumsi dan tingkat pemenuhan nutrien dari bahan pakan yang dikonsumsi.

\section{Konsumsi bahan organik}

Kemampuan konsumsi bahan organik per $\mathrm{kg}$ berat badan kambing Kacang dan kambing PE secara statistik juga menunjukkan kemampuan yang relatif sama, baik pada saat pakan dikurangi maupun saat pakan diberikan secara ad libitum, namun dapat dilihat bahwa jumlah konsumsi bahan organik untuk setiap $\mathrm{kg}$ berat badan kambing Kacang sedikit lebih tinggi daripada kambing PE. Hal tersebut disebabkan karena tingkat konsumsi bahan kering kambing Kacang sedikit lebih tinggi dari kambing PE.

Menurut Cakra et al. (2005), bahan organik berkaitan erat dengan bahan kering. Sebagaimana diketahui bahwa bahan organik merupakan bagian terbesar dari bahan kering, sehingga jumlah konsumsi bahan organik sangat ditentukan oleh jumlah konsumsi bahan kering pakan. Pada Tabel 1 terlihat bahwa konsumsi bahan organik per kg berat badan kambing terpaut hanya 2-3 g di bawah konsumsi bahan kering pakan.

Konsumsi bahan organik pakan meningkat sangat nyata ketika pakan diberikan secara ad libitum. Konsumsi bahan organik per kg berat badan kambing pada saat pakan dikurangi adalah $15,70 \mathrm{~g}$ dan ketika pakan diberikan secara ad libitum konsumsi meningkat menjadi 25,66 g. Pemberian pakan sepuasnya telah memberikan kesempatan kepada ternak untuk mengkonsumsi pakan sesuai dengan batas kemampuannya sehingga berat badan juga akan cenderung mengalami peningkatan. Demikian juga sebaliknya, dengan meningkatnya berat badan ternak maka konsumsi pakan juga cenderung akan semakin meningkat.

\section{Kecernaan bahan kering dan bahan organik}

Analisis Sidik Ragam menunjukkan adanya pengaruh yang sangat nyata $(\mathrm{P}<0,01)$ dari perlakuan pakan terhadap kecernaan bahan kering dan kecernaan bahan organik pakan, akan tetapi tidak ada interaksi antara faktor bangsa kambing dan jumlah pakan untuk mempengaruhi parameterparameter tersebut. Adanya perbedaan kecernaan bahan kering dan kecernaan bahan organik pakan adalah merupakan pengaruh faktor tunggal dari bangsa kambing dan jumlah pakan yang diberikan, 
feses lebih sedikit dan yang dapat dicerna cukup besar. Keunggulan mencerna bahan pakan yang lebih baik tentunya akan berdampak positif terhadap penampilan ternak kambing terutama perubahan berat badan.

Kecernaan bahan kering saat pakan dikurangi berbeda sangat nyata dengan kecernaan pada saat pakan diberikan secara ad libitum. Nilai KCBK pada saat pakan dikurangi adalah $74,70 \%$ dan ketika pakan diberikan secara ad libitum KCBK meningkat menjadi $81,28 \%$. Jumlah bahan pakan yang diberikan ternyata mempengaruhi tingkat kecernaan zat makanan. Pengurangan jumlah pakan selama satu bulan telah menyebabkan rata-rata daya cerna terhadap bahan pakan juga menjadi menurun.

Rendahnya koefisien cerna bahan pakan merupakan akumulasi dari terbatasnya pakan yang diberikan. Konsumsi pakan merupakan akibat langsung dari pengurangan pakan. Dengan konsumsi yang rendah akan mengakibatkan berat badan ternak mengalami penurunan. Menurut Yuwono et al. (2000), kehilangan berat badan akan diikuti oleh penurunan ukuran dan berat organ tubuh, dan saluran pencernaan merupakan organ yang sangat peka terhadap pengurangan pakan. Dijelaskan pula bahwa pada domba yang mengalami laju penurunan berat badan sebesar $133 \mathrm{~g}$ per hari akan terjadi penurunan berat saluran pencernaan sebesar $62 \%$. Menurunnya ukuran saluran pencernaan tentunya akan mempengaruhi kemampuan konsumsi dan daya cerna terhadap bahan pakan.

Peningkatan kecernaan bahan kering pada saat pakan diberikan secara ad libitum sejalan dengan peningkatan konsumsi bahan kering. Telah dijelaskan sebelumnya bahwa dengan pemberian pakan secara ad libitum maka ternak mendapat kesempatan untuk mengkonsumsi pakan sepuasnya. Kondisi tersebut juga memungkinkan lebih banyak pakan yang dapat dicerna. Meningkatnya konsumsi pakan memacu aktivitas mikroba rumen dalam mencerna bahan pakan (Farida, 1998) sehingga meningkatkan laju fermentasi di dalam rumen. Peningkatan kecernaan bahan kering akan berpengaruh juga terhadap kecernaan zat-zat makanan yang lain.

Kecernaan bahan organik. Analisis statistik menunjukkan ada perbedaan kecernaan bahan organik antara kambing Kacang dan kambing PE. Pada Tabel 2 terlihat bahwa nilai KCBO dari kambing PE adalah 82,65\%, lebih tinggi dari pada nilai KCBO pada kambing Kacang yakni sebesar $79,11 \%$. Tingginya KCBO kambing PE dibandingkan kambing Kacang memberi gambaran bahwa nutrien pakan ternyata lebih banyak diabsorbsi pada kambing PE. Dapat pula dijelaskan bahwa bagian nutrien pakan yang tidak diekskresikan melalui feses lebih besar diperlihatkan oleh kambing PE. Tillman et al. (1998) menjelaskan beberapa faktor yang dapat mempengaruhi kecernaan pakan, di antaranya adalah jenis atau bangsa ternak.

Kecernaan bahan organik saat pakan dikurangi berbeda sangat nyata dengan kecernaan pada saat pakan diberikan secara ad libitum. Nilai KCBO pada saat pakan dikurangi adalah $77,65 \%$ dan ketika pakan diberikan secara ad libitum maka KCBO meningkat menjadi $84,11 \%$. Jumlah pakan diberikan menurut Tillman et al. (1998) adalah salah satu faktor yang dapat mempengaruhi tingkat kecernaan zat makanan. Rendahnya KCBO merupakan akibat langsung dari rendahnya konsumsi bahan organik pada saat pakan dikurangi. Sebagimana telah dijelaskan bahwa konsumsi yang rendah mengakibatkan berat badan bahkan ukuran organ saluran pencernaan akan ikut menurun sehingga berdampak pada kemampuan konsumsi dan daya cerna. Kecernaan bahan organik menjadi meningkat saat pakan diberikan secara ad libitum. Peningkatan tersebut mengikuti peningkatan konsumsi bahan organik dimana pemberian pakan yang banyak telah memberikan kesempatan pada ternak mengkonsumsi pakan dalam jumlah yang cukup sehingga memacu akvifitas mikroba rumen untuk mencerna pakan lebih banyak.

\section{Kesimpulan}

Kambing Kacang dan kambing PE menunjukkan pola konsumsi bahan kering dan bahan organik yang sama. Saat pakan dikurangi maka konsumsi akan menurun, dan ketika pakan diberikan secara ad libitum maka konsumsi akan meningkat secara signifikan. Kambing PE mampu mencerna bahan kering dan bahan organik lebih baik dari kambing Kacang baik pada saat pakan dikurangi maupun saat pakan diberikan secara $a d$ libitum. Pengurangan pemberian jumlah pakan pada kedua bangsa kambing tersebut menyebabkan kecernaan bahan kering dan bahan organik menjadi menurun dan meningkat secara signifikan ketika pakan diberikan secara ad libitum.

\section{Daftar Pustaka}

Arora, S. P. 1995. Pencernaan Mikroba pada Ruminansia. Terjemahan: R. Murwani. Gadjah Mada University Press, Yogyakarta. 
Cakra, I. G. L. O., I. G. M. Suwena, dan N. M. Sukmawati. 2005. Konsumsi dan koefisien cerna nutrien pada kambing Peranakan Etawah (PE) yang diberi pakan konsentrat ditambah soda kue (Sodium bikarbonat). Available at $\mathrm{http} / / \mathrm{ojs}$.unud.ac.id/index. $\mathrm{php} / \mathrm{mip} /$ article/view/1692/1006. Accession date: 15 Desember, 2011.

Devendra, C. dan M. Burns. 1994. Produksi Kambing di Daerah Tropis. Terjemahan: IDK Haryaputra. Penerbit: ITB, Bandung.

Farida, W. R. 1998. Pengimbuhan konsentrat dalam ransum penggemukan kambing muda di Wamena, Irian Jaya. Media Veteriner 5: 2126.

Hanafia, K. A. 2010. Rancangan Percobaan, Teori dan Aplikasi. Rajawali Press, Jakarta.

Mulyono, S. dan B. Sarwono. 2010. Penggemukan Kambing Potong. Penebar Swadaya, Jakarta.

Orskov, E. R. 1988. The Feeding of Ruminant Principles and Practice. Chalombe publ., Marlow.

Paramita, W. L., W. E. Susanto, dan A. B. Yulianto. 2008. Konsumsi dan kecernaan bahan kering dan bahan organik dalam haylase pakan lengkap ternak sapi Peranakan Ongole. Media Kedokteran Hewan 24: 59-62.
Tillman, A. D., H. Hartadi, S. Reksohadiprodjo, S. Prawirokusumo, dan S. Lebdosoekojo. 1998. Ilmu Makanan Ternak Dasar. Gadjah Mada Univesity Press, Yogyakarta.

Utomo, R. 2003. Penyediaan pakan di daerah tropik: Problematika, kontinuitas, dan kualitas. Pidato Pengukuhan Jabatan Guru Besar. Fakultas Peternakan Universitas Gadjah Mada, Yogyakarta.

Wirawan, I. W., I. M. Mudita, I. G. L. O. Cakra, N. M. Witariadi, dan N. W. Siti. 2008. Kecernaan nutrien kambing Peranakan Etawa yang diberi pakan dasar rumput lapangan disuplementasi dengan dedak padi. Laporan Penelitian. Fakultas Peternakan Universitas Udayana, Denpasar.

Yusmadi. 2008. Kajian mutu dan palatabilitas silase dan hay ransum komplit berbasis sampah organik primer pada kambing PE. Tesis. Program Pascasarjana, Institut Pertanian Bogor, Bogor.

Yuwono, P., B. Hartoyo, A. Priyono, dan H. Soeprapto. 2000. Intik pakan dan pertumbuhan domba yang diberi pakan rumput lapangan setelah pengurangan pakan selama 6 minggu. Anim. Prod. 2: 47-52. 